\title{
Lordosis in topsmelt Atherinops affinis (Ayres, 1860) (Teleostei: Atherinopsidae)
}

\author{
Lordosis en el pejerrey Atherinops affinis (Ayres, 1860) \\ (Teleostei: Atherinopsidae)) \\ *José De La Cruz-Agüero and Liduvina Perezgómez-Alvarez \\ Centro Interdisciplinario de Ciencias Marinas. Colección Ictiológica (CI). \\ Apartado Postal 592. La Paz, Baja California Sur, México 23000 \\ *Becario COFAA, EDI-IPN \\ jcruz@redipn.ipn.mx
}

\begin{abstract}
Resumen.- Se describe por primera vez un caso de lordosis (curvatura de la columna vertebral) en el pejerrey Atherinops affinis, a partir de un ejemplar recolectado en la Laguna Ojo de Liebre, Baja California Sur, México.

Palabras clave: Atherinops affinis, anormalidades, deformación vertebral.
\end{abstract}

\begin{abstract}
The first report of lordosis (vertebral curvature) in topsmelt Atherinops affinis is described from one specimen collected at Laguna Ojo de Liebre, Baja California Sur (México).

Key words: Atherinops affinis, abnormalities, vertebral deformation.
\end{abstract}

Several authors have reported skeletal deformities for many species of fish that affect the cranium, vertebral column, ribs, and fins. Such abnormalities have been described in natural populations (e.g., Dawson, 1964, 1966, 1971; Dawson \& Heal, 1976) or induced experimentally in a laboratory by stimuli such as temperature, salinity, dissolved oxygen, radiation, nutritional deficiency, and physical and mechanical irritations (Haaker, 1977). Moreover, skeletal deformations of fish have been successfully correlated with sewage discharges and industrial effluents (Lindesjoo \& Thulin, 1992) or caused by parasitism (e.g., Szidat \& Nani, 1951).

We report here our observations on vertebral column deformity in a topsmelt Atherinops affinis (Ayres, 1860). Other authors have reported skeletal abnormalities for Atherinidae (e.g., Rodriguez et al., 1990) but to our knowledge not many have referred to vertebral columns (e.g., Cabrera, 1963; Szidat \& Nani, 1951). Atherinops affinis occurs along the Pacific coast from Vancouver Island (Canada) to Baja California Sur (México), and in the upper Gulf of California (De La Cruz-Agüero et al., 1997).

On 7 September 1994, we collected nearly four hundred specimens of the topsmelt A.affinis (CICIMAR-CI 4121). The fish were caught by beach seines in a small coastal inlet known as Las Casitas at Laguna Ojo de Liebre, B.C.S., Mexico (27²5'N $\left.114^{\circ} 0^{\prime} \mathrm{W}\right)$. Fish were between 56 and $127 \mathrm{~mm}$ total length. We caught the following species in the same casts (De La Cruz-Agüero et al., 1996): Illypnus gilberti (Eigenmann and Eigenmann, 1889), Hypsopsetta guttulata (Girard, 1856), Paralichthys californicus (Ayres, 1859), Exerpes asper (Jenkins and Evermann, 1889), and Sphoeroides annulatus (Jenyns, 1842). From the specimens of $A$. affinis, one of them was noticeably twisted along its midlateral axis. We observed no external lesions. To reveal the extent of the abnormality, we decided to clear and stain the specimen using an enzyme method (Taylor, 1967). First we ran a test of the method with four apparently normal specimens to calibrate solutions and time processes before testing the twisted specimen (Fig. 1a). From the specimens in the test, one of them had an abnormality concerning to the elements of the anal fin without effect on the external appearance of the fish. It concerned splitting of the eleventh anal pterygiophore. The abnormal specimen once cleared and stained, showed dorsoventral vertebral curvature (lordosis). Deformation starts at vertebra nine, and never forms a normal position, with the consequent deformation of the vertebral column and neural and hemal spines. We saw no vertebral fusion, but the ventral sections of the vertebral body are clearly compressed at vertebrae $15-17$ and to a much greater extent at vertebrae 35-37 (Fig. 1b).

Different authors have implicated skeletal deformities of fish as possible indicators in pollution monitoring programs (Lindesjoo \& Thulin, 1992). Therefore, it is important that occurrences of these and other abnormalities be reported (Haaker, 1977).

Industrial activities occur near the area where the present specimens were collected. At different times in the same locality, we have caught specimens of abnormal rajiform fish (e.g., truncated tail and double 
stinging spines). However, because of the isolated observations and lack of data on the aquatic environment, we cannot establish any correlation between these anomalies and the industrial activities.

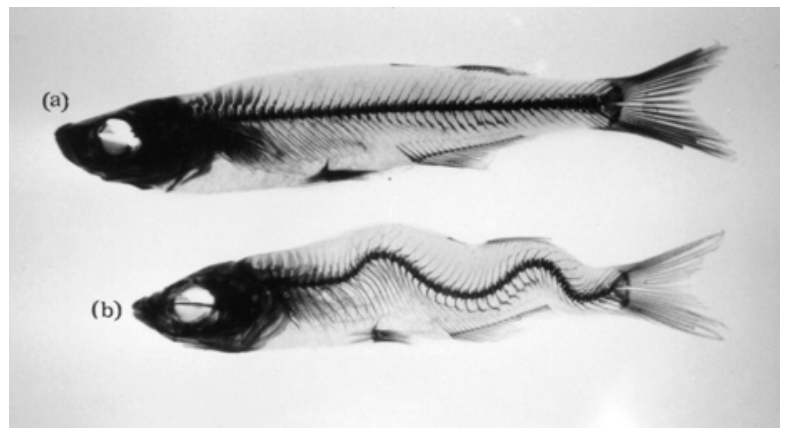

Figure 1

Topsmelts (Atherinops affinis) caught at Las Casitas, laguna Ojo de Liebre, B.C.S. (México). (a) Without vertebral deformation (test run) and (b) with dorsoventral vertebral curvature (lordosis)

Pejerreyes (Atherinops affinis) recolectados en Las Casitas, laguna Ojo de Liebre, B.C.S., México. (a) Sin deformación vertebral (organismo de prueba) y (b) con deformación dorsoventral en la columna vertebral (lordosis).

\section{Literature cited}

Cabrera SE. 1963. Sobre un ejemplar deformado de pejerrey (Basilichthys bonariensis) encontrado en Punta Lara. Neotropica 9 (28): 38-40.

Dawson CE. 1964. A bibliography of anomalies of fishes. Gulf Research Reports. 1(6): 308-399.
Dawson CE. 1966. A bibliography of anomalies of fishes. Gulf Research Reports 2 (2): 169-176.

Dawson CE. 1971. A bibliography of anomalies of fishes. Gulf Research Reports 3 (2): 215-239.

Dawson CE \& E Heal. 1976. A bibliography of anomalies of fishes. Supplement 3. Gulf Research Reports 5: 35-41.

De La Cruz - Agüero J, M Arellano \& VM Cota. 1996. Lista sistemática de los peces marinos de las Lagunas Ojo de Liebre y Guerrero Negro, B.C.S. y B. C., México. Ciencias Marinas 22 (1): 111-128.

De La Cruz - Agüero J, M Arellano, VM Cota \& G De La Cruz - Agüero. 1997. Catálogo de los peces marinos de Baja California Sur, 346 p. CONABIO-IPN, México, D.F.

Haaker PL. 1977. Abnormal vertebral development in northern anchovy, Engraulis mordax Girard. California Fish and Game 63:182-185.

Lindesjoo E \& J Thulin. 1992. A skeletal deformity of northern pike (Esox lucius) related to pulp mill effluents. Canadian Journal of Fisheries and Aquatic Science. 49: 166-172.

Rodriguez RJ, R Ramirez \& G Nuñez. 1990. Deformación de la boca en un juvenil de Atherinops affinis (Ayres) (Pisces: Atherinidae) desarrollado en laboratorio. Investigaciones Marinas CICIMAR 5 (2): 143-146.

Taylor WR. 1967. An enzyme method of clearing and staining small vertebrates. Proceedings of the United States National Museum.122 (3596): 1-17.

Szidat L \& A Nani. 1951. Diplostomiasis cerebralis del pejerrey. Revista del Instituto Nacional de Investigacion de las Ciencias Naturales, Buenos Aires. 1 (8): 323-384. 